Original Paper

\title{
A Social Survey for Economic Valuation of Health Risk Reduction in Shanghai
}

\author{
Noboru NOMURA \\ (Received May 21, 2010)
}

\author{
上海市における健康リスクの経済評価 \\ 野村 昇
}

\begin{abstract}
In the procedure of the life cycle assessment complying with ISO 14000 series, impact assessment is required. For the integrated assessment of impacts, evaluation with economical values is frequently applied. Evaluating impacts of damages on human health, it is converted to economical value using method of environmental economics. One of the ways to determine the rates of conversion is to presume residents' willingness to pay to avoid the damages. These rates are estimated by analyzing data observed through social survey, but knowledge of the conversion rates in developing countries is not sufficient. We launched a social survey in Shanghai to analyze willingness to pay to decrease risks contracting asthma caused by air pollution. Five hundred subjects were sampled by multistage area sampling. Subjects were sampled from all of the districts of Shanghai. They were asked their willingness to purchase an air purifier to reduce risks to contact asthma with presented prices for the analysis of contingent valuation method, as well as their profiles. The answers were analyzed by fitting log-logistic distributions and factors that influence the willingness were examined.
\end{abstract}

\section{Key Words}

Contingent Valuation Method, Willingness to pay, Air pollution

\section{1. はじめに}

地球温暖化問題の重要性が増し，温室効果ガス排出量の削 減が強く求められている。気候変動枠組み条約の京都議定書 では，先進工業国へ温室効果ガス削減について合意がなされ， 2008 年からの 5 年間である第 1 約束期間もほぼ半分が経過し た。京都議定書では国際的に協調をして約束を達成する仕組 みである京都メカニズムも採択されている。その一つである クリーン開発メカニズム (clean development mechanism ; CDM） は，温室効果ガスの排出量の削減義務を負っていない 発展途上国に扔ける排出量をベースラインと呼ばれる基準よ り削減するプロジェクトの実施を先進国が支援をし，削減さ れた排出量をプロジェクト実施先進国の排出削減量にカウン トするものである。CDMを実施する主目的は温室効果ガス削 減であるが，最近は電力設備の向上による大気污染物質排出 量削減等の副次的便益 (cobenefit) 積極的に評価する機運が 高まっている。副次的便益の評価には，供給価格に反映され

National Institute of Advanced Industrial Science and Technology (AIST)

16-1, Onogawa, Tsukuba-shi, Ibaraki 305-8569, Japan
ていない環境負荷等の外部コストの評価が必要となる。

電力システムの外部コスト評価を目的としてEUにおいて

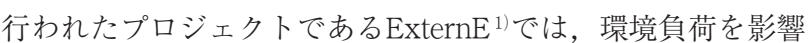
経路法（Impact Pathway Approach；IPA）により分析してい る。この方法では，大気污染による人間への健康被害の外部 性を評価する場合は, 発生量評価, 拡散挙動解析, 暴露応答 解析，貨幣価值化の段階を踏んだ評価を行うことになる。発 生量評価では，機能単位である発電電力量当たりの浮遊粒子 状物質 $(\mathrm{PM}), \mathrm{NOx}$ 等の污染物質排出量の評価が行われる。拡 散挙動解析では，污染物質の大気中への拡散や，NOx，揮発性 有機化合物（VOC）により生成が促進されるオゾンの発生を 推定し, 各地点の有害物質濃度の上昇が推定される。暴露応 答解析では，死亡率，罹患率の増大量が推定され，貨幣価值 化ではこれの経済価值への換算が行われる。Hainoun et al. ${ }^{2}$ で は，IPAによるシリアの電力システムの評価を行っている。ま た，ライフサイクルアセスメントに拈いては，評価対象の比

(独) 産業技術総合研究所

干 305-8569 茨城県つくば市小野川 16-1 
較のためにインパクトを統合評価が有用であり，統合指標を 貨幣価值で表すことも多い。日本版被害算定型影響評価手法 ${ }^{3)}$ (Life-cycle Impact assessment Method based on Endpoint modeling ；LIME）でも IPA と同様な方法で “被害算定”を行 い，貨幣価值換算された指標も提供されている。

これらの指標を構成する過程における貨幣価值換算におい て, 人の健康被害については, 死亡率, 罹患率に関わるもの の両方が評価されている ${ }^{1)}{ }^{3)}$ 。死亡率変化の貨幣価値換算で は，人的資本法，ヘドニック法，表意選好法等が適用される。 人的資本法は，健康被害による損失を評価するときに，健康 についての被害により失われた所得に基づいて価值換算を行 うものである。この方法では，死亡等のリスクを事象が発生 したときに失われる所得を現在価値に割り戻す等の方法がと られている。これに対してへドニック法では，財市場におい て污染水準や健康リスクにより，地代，賃金等が変化するこ とを分析することにより経済価值の推定を行おうというアプ ローチである。賃金についての分析は，環境負荷に限らず事 故等のリスクを対象にしての分析も行われており，賃金リス ク法を他のへドニック法と分けて考える考え方もある4)。この 方法は，市場で現に取引されているという意味で，現実の社 会で評価されている経済的な価值を反映している一方で，環 境負荷により価格が変動した部分を他の要因から分離するこ とは容易ではなく，デー夕取得の面でも困難な点がある。

仮想評価法 (Contingent Valuation Method；CVM) に代表さ れる表明選好法 ${ }^{5}$ ～7) では，多数の回答者に環境負荷の変化に ついてのシナリオを提示して選好を直接質問し，得られた回 答を統計的に分析して支払意志額 (Willingness To Pay;WTP) に基づき経済価值の推定を行う方法であり，他の方法で推定 が困難な評価対象についての適用が可能である。

一方，死亡に至らないまでも污染起源の罹患について， Bickel and Friedrich ${ }^{1)}$ では，医療費等の “コスト”，労働損失 等の “機会費用”，痛み等を含む “その他損失”の 3 種の評価 対象を挙げて欧州における評価額についての情報をそれぞれ 収集しており，入院 1 回 2,000 ユーロ，労働損失 1 日 82 ユー 口，服薬 1 日 1 ユーロ等の值が揭げられている。これらの貨 幣価值換算においも，評価対象によってはCVMにより推定さ れた值が用いられている。

発展途上国のなかでも経済発展の著しい国の都市の大気污 染は深刻な状況とされている。Pearce ${ }^{8)}$ は，発展途上国におけ るPM及び鉛への暴露の重大さを強調している。また例えば世 界銀行による報告 ${ }^{9}$ によるる 記載) の上海市や北京市において浮遊粒子状物質 (SPM) の濃 度は，WHOの基準である $90 \mu \mathrm{g} / \mathrm{m}^{3}$ を大きく上回る上海で 246 $\mu \mathrm{g} / \mathrm{m}^{3}$ ，北京で $377 \mu \mathrm{g} / \mathrm{m}^{3}$ とされている。従って，その評価 は重要である。中国においても，大気污染低減に対するWTP についての調査がいくつか行われている。Wang \& Mullahy ${ }^{10)}$ では，市当局が実施する大気污染起因の死亡率減少プロジェ クトに対してのWTP を重慶市で調査している。WTP の平均 は 14.3 元, これより計算される確率的生命価値（VSL; Value of Statistical Life) 推定值は 34,458米ドルとされている。一方,
Hammitt \& Zhou ${ }^{11)}$ では都市規模の異なる 3 地点で, 風邪, 慢 性気管支炎, 死亡回避へのWTPを調查した。推定されたVSL は, 地点, 適用モデルにより差があるものの，15,000 ドルか ら 180,000 ドルとされている。Wang, et al. ${ }^{12)}$ では, 北京市の 大気污染の改善について，污染が50\%減少することに対する WTP を調査し，WTPに影響を与える因子を分析している。 Wang \& Zhang ${ }^{13)}$ でも, 山東省済南市において大気污染を改 善することに対するWTPを調査し，先行研究 10) 12) を含む調 査について比較を行い，WTP と所得との比率，0.4\%から 4.1 \%であること，疾患に関係する対象についてWTPが高めであ ることが指摘されている。

しかしながら，先進国に比べて中国をはじめとする発展途 上国においては，健康被害の貨幣価值についての十分な蓄積 が行われている状態には達していない一方で, 最近の著しい 経済発展の状況から所得等の条件が変化してきており, 継続 的な分析が重要と考えられる。また，大気污染の評価には， IPAを背景とした方法, 環境改善プロジェクトを直接評価対象 とする方法を評価する場合 ${ }^{10)}$ 等, アプローチが複数有り，対 象とされるエンドポイントも多様である。さらに，WTPに影 響を及ぼす要因の分析も完全には解明されていない。本報で は，以上のことを鑑みて，CDMの総合評価を念頭に中国上海 市における大気污染による健康被害に対するWTPについての CVMによる評価を中心とした環境意識についての調査につい て報告する。

\section{2. 調査対象と方法}

\section{1 調査対象世帯の抽出}

調査は，上海市内に扔ける一般世帯の 20 歳から 59 歳まで の居住者を対象として 2008 年 9 月から 10 月にかけて訪問面 接法により実施した。対象世帯の抽出では，無作為抽出によ り上海市市内の居民委員会を選び，各居民委員会のなかから 開始世帯を決定し，住居を順に直接訪問して回答を依頼する 方法を用いている。調査のばらつきを抑えるため，一箇所か らの抽出世帯数は 10 軒以内とした。調査に協力する世帯が得 られたとき，質問の本体部分に入る前に世帯の構成員につい て質問を行い，調査対象年齢の構成員から無作為に 1 人を選 び回答を依頼した。なお，報道機関，広告，調査会社関係者， 過去半年以内に類似の調査を受けたひと，引っ越してから半 年以内のひとは調查対象者から除外した。サンプル数は 500 件で，サンプリングにより上海市を構成する19の区全てから 回答者を得ている。調査に先立ち，2008年 1 月に予備調査を 実施して調査票の妥当性について検討を行い，修正をした調 査票を本調査で用いている。

\section{2 調査票の構成}

調査では，大気污染による引き起こされる健康リスクのう ち, 死亡率を変化させない喘息罹患に対するリスク低減と死 亡率低下の両者に対する支払意志をCVMにより分析すること を主目的とした。これは，LIMEにおいて大気污染による健康 被害についての係数が，この 2 種類について提供されている 
ことを考慮したものである。本報では，このうち喘息罹患に 対するリスク軽減についての分析について報告する。質問票 では，CVMによる分析を行うための設問を中心に配置して， その前に環境問題及び大気污染に関連する設問を配した。こ れは，分析を行うための回答を得る他に，CVMの設問の前提 を回答者に思い起こさせることを目的としている。CVMの設 問の後ろでは，世帯年収，職業等の回答者の属性と環境意識 に関連した設問を質問した。

CVM の設問に入る直前の質問では，「あなたは喘息等の風 邪等を除く呼吸器系の病気に罹っていますか。」質問し回答 を得た後，「あなたが住んでいる地域，働いている地域の環境 についてどう思いますか？」と質問を行い，大気污染に対す る認識の選択肢を示し，健康被害について回答者が話題に注 目するように配慮した。その後に，CVMの設問を配置した。質 問では，発電所等で発生する細かい塵で健康が害されること があることを説明し，今後10年間に喘息にかかる確率が $10 \%$ であると仮定を行った。そして，自宅の寝室に空気清浄機を 設置して健康への影響を減らせる選択肢を示した。また，喘 息の症状で咳が出始めたとき，薬で症状を止めることが可能 であり，他への影響はなく，その薬は政府から無料で支給さ れるとした。

大気污染に起因する被害が評価対象であるため，被害とし て大気污染に起因して喘息になることとし，支払対象として 空気清浄機を取り上げた。質問は，大気污染により今後 10 年 間において喘息になる確率が何もしない場合 $10 \%$ であると仮 定を行い，これが空気清浄機を設置すると罹患率が 8 \%ない し 6 \%に減少するときのWTPを尋ねた。これらの確率は，あ る程度現実味を感じる程度に大きめな值に設定した。

喘息に罹患すると，仕事，日常生活上の支障や通院のため の時間的損失等の影響があると考えられ，発作の強弱も多様 と考えられるため，ここでは対象の範囲を限定するために発 作は薬で抑えられ，薬は無料で支給されると想定した。死亡 率の変化については，明示すること自体が回答に影響を与え る恐れがあるため，他の影響はないと表現に死亡率が不変で あることが含まれると考えた。

大気污染による被害を評価するに当たり，污染自体を低減 させる費用を負担するか否かを直接質問する方法も考えられ る。例えば，地方政府が大気污染を減少させるプロジェクト を実施し，その費用のために回答者を含む住民が負担すると いう質問方法もがあり，先行研究 1012113) でもこの方法が用い られている。しかしながら，大気污染の緩和という便益は公 共財的性質を持ち，支払の有無により特定の集団だけが良い 大気環境を享受するという排除性は想定できない。この様な 場合に，自由意志での支払の有無を回答するCVMを直接的に 用いるとフリーライダー的回答を誘発する可能性があり得る ため，ここでは大気污染物質の濃度の低減に対して支払意志 の有無を直接質問するのではなく，被害を低減させる機器を 購入する購入意志を尋ねる方法をとった。被害を低減させる 機器による健康状態の改善を購入しないひとは享受できず, ただ乗りを前提とした回答によるバイアスが低減することが
期待される。購入意志を尋ねる対象として代替物への支出を 質問することは，松岡ら ${ }^{14)}$ でも「大気污染から健康を守る様々 な手段（マスク，飲み薬，うがい薬など)」への支払意志の有 無を質問する方法で行われている。空気清浄機という特定の 機器についての支払意志を質問することは，健康被害を低減 する手段を一般的に質問する方法に比べ，回答者がより状況 を想定しやすくなるという利点がある。一方で, 特定の機器 を例示することにより，機器に対する選好が回答に影響する 危険性も発生する。空気清浄機を評価対象とするため, 室内 環境を快適にすることに対する選好による支払意志が働く可 能性があるものの，質問の直前で呼吸器疾患と大気污染に関 連した質問を行っており，質問の流れからも機器を示した理 由が大気污染による被害の削減から明らかにしており，今回 の支払意志の有無は健康に対する被害の減少によるものが大 部分だと判断して分析を進めた。また，CVMの質問において は，回答者が質問の趣旨を理解した上で回答を行っているこ とが重要となる。今回の調査においては, 調査員が回答者に 面接形式で一問々々に質問を行っており，回答者による質問 の意味の理解度は高いと推定される。

支払対象とした機器である空気清浄機の保有の有無につい ては，他の機器も含めてCVMに関わる設問より後ろで尋ねた ところ，保有世帯は調查対象となった世帯には存在しなかっ た。

\section{3 支払意志額の質問方法}

CVM によりWTP を尋ねる質問では，支払意志のある上限 金額を直接質問する方法の他に，金額を提示してこれに対し て支払の意志の有無を尋ねる二肢選択法が多用される。また， 二肢選択法では一回の質問によりWTPが提示金額以上か，そ れ未満かという情報しか得られないため，情報量を増やすた めに 1 回目の回答を得てから金額を変更して再度支払意思を 尋ねる二段階二肢選択法も多用される。二回目に提示する金 額は，一回目に支払意志があると答えた回答者に対しては増 大させ，支払意志無しと答えた回答者に対しては減少させる ことになる。今回の調査では調査項目が罹患率，死亡率とい うパラメータを持ち得るものであり，限られた回答者と質問 数から少しでも多くの情報を得る試みとして選択肢を 3 つと して質問を行った。また，二段階二肢選択法に倣い質問は 2 回行い，2 回目の質問では 1 回目の回答に基づき提示する金 額を変更する方法を用いた。

質問を行うときに 3 つの選択肢を用いる方法は，Loomis et al. ${ }^{15)}$ でも提案されている。Loomis et al. ${ }^{15)}$ では，CVMによる データにより推定されるWTPが高めになるバイアスを回避す るための方法として三肢選択を提案している。そこでは，提 示額よりWTPが小さい回答者が金額によっては支払意志があ ることを示すために二肢選択に拈いて支払うと回答する場合 があり，これがバイアスの発生原因としている。これを避け るため，提示額を示したときに提示額以上に支払うという選 択肢の他に，提示額より低い支払をする，支払をしないとい う合計 3 つの選択肢を準備することを提案している。一方，本 
研究では調査に対する回答については信頼をし, 回答から得 られる情報量を増すことに着目して選択肢を構成した。喘息 になる確率を $6 \%$ ，8％にするために空気清浄機に要する費 用を提示し，高い提示額 VH の支出を行い，罹患率が $6 \%$ に 低下すること（選択肢 $\mathrm{CH}$ ), 低い提示額 VL の支出を行い罹 患率が $8 \%$ になること (同 CL) 及び空気清浄機を購入せずに 罹患率 10\%のまま（同 CZ）という 3 種の選択肢からの一番好 ましいものを選択する形式とした。罹患率が $6 \%$ となること (事象 $\mathrm{AH})$ は，8\%となること（同 $\mathrm{AL}$ ) よりも好ましいこと であり，これに対するWTPはALに対するそれより小さくは ならない。

回答者が選択肢CZを選択した場合，事象AHに対するWTP はVHより小さく，事象 ALに対しても WTPはVLより小さ い。Fig.1にこの様子を示す。図中では，事象ALに対するWTP の存在範囲を点線，事象AHに対するWTPの存在範囲を実線 で示した。回答者が $\mathrm{CH}$ 選択することは，事象 $\mathrm{AH}$ に対する WTP がVH 以上であることになる。このとき，事象 AL に対 するWTPの存在範囲は一般には決まらない。回答者が選択肢 CLを選択した場合, 直接的には小さい方の罹患率減少が起こ る事象 ALに対して低い提示金額 VL 以上の WTP があること になる。一方，より低い罹患率となる事象 $\mathrm{AH}$ に対しては事 象ALより小さくない効用があるはずであるため，これに対す る WTP も VL 以上となる。

Table 1に提示した金額を人民元単位で示す。一回目の質問 での提示額をVL1，VH1 と記した。提示金額は，最初にA1， B1, C1の 3 種を用いて調査を開始し, 調査途中で集計を行い 回答分布を検討して提示額の修正行った。修正は 2 回行い計

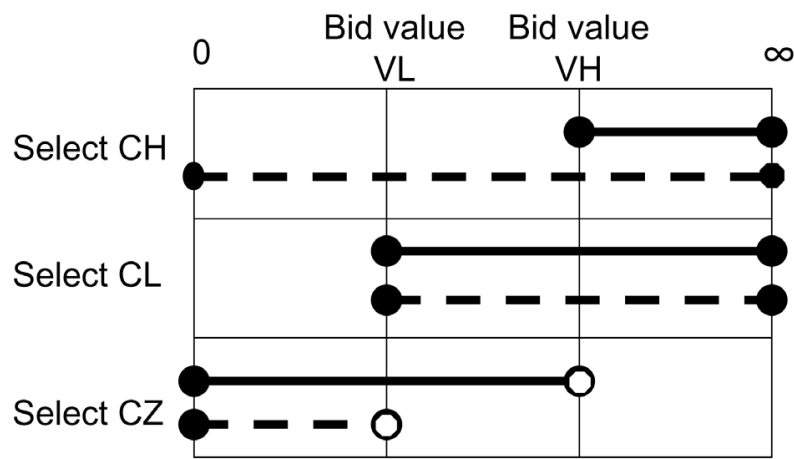

Fig. 1 Possible WTP value with each choice for trichotomous selection
9 種類の質問票を用いた。回答者には，その時点で用いられ ている 3 種の調査票の内 1 つが割り当てられることになる。 1 回目の提示額に対する回答にもとづき，2 回目の提示金額 を回答者毎に分岐して提示した。1 回目の設問で，選択肢 $\mathrm{CH}$ を選択した場合，事象AHに対するWTPは，1 回目の提示額 VHより高い。また，高い提示額を受容しているため，事象 $\mathrm{AL}$ へのWTPも高いことが期待される。このため, VH, VL共に 1 回目より高い金額VH2h，VL2hを 2 回目の質問で提示した。 1 回目の設問に対してCZを選択した場合，各罹患率に対する WTPはVL1, VH1より低いため, VL, VH共に1回目より低 い金額 VL2z，VH2zを提示した。1 回目に選択肢CLを選択し た場合，事象ALに対するWTPはVL1より大きい。このため， 2 回目の事象 ALに対応する提示額 VL21 はVL1より大きくし た。事象 AH に対するWTPのVH1 との大小関係はこの回答 だけでは決まらないものの, AH に対する 2 回目の提示額 VH21は，VL21より大きくする必要はある。1 回目の質問では VH1はVL1の 3 倍の金額を提示しており，また罹患率減少率 が数值の上では事象 AHではALの 2 倍になることを考慮して VH21 はVL21の 2 倍となるように設定した。

\section{3. 調査結果の分析}

\section{1 前提となる質問への回答結果}

調査では, 環境問題に対する認識についての質問を最初に 行い，次に健康に関わる質問を行った後，CVMに関する設問 に移る様にした。環境問題に関する設問では，地球温暖化問 題についての知識とどの程度協力する意志があるかを尋ねた。 「二酸化炭素等の温室効果ガスにより, 地球温暖化問題が起こ る可能性があることを聞いたことがありますか」と尋ねたと ころ，80\%の回答者が聞いたことがあるとしていた。一方， 2008 年から 2012 年までの先進国の温室効果ガス排出量制限 についての1997年に締結された京都議定書についての知識に ついて,「削減対象の気体の種類を 3 種類以上知っている」, 「その様な話があることは知っていた」，「初めて聞いた」の選 択肢から選ぶ設問では，51\%の回答者が初めて聞いたとして おり，規制対象の気体を 3 種以上知っているとしたのは $5 \%$ であり，中国が排出量削減義務を持たないことも背景にある のか, 地球温暖化についての知識に比べ知られていなかった。 地球温暖化問題の存在をマスコミ経由で知ったのは，4〜 5 割であり, 口コミは 3 割, 学校で習ったのは $5 \%$ 以下であっ

Table 1 Bid value for the survey in RMB

\begin{tabular}{|c|c|c|c|c|c|c|c|c|c|c|}
\hline & & A1 & B1 & $\mathrm{C} 1$ & $\mathrm{~A} 2$ & B2 & $\mathrm{C} 2$ & A3 & B3 & $\mathrm{C} 3$ \\
\hline \multirow{2}{*}{ First Bid } & VL1 & 1,000 & 4,000 & 16,000 & 1,000 & 4,000 & 2,000 & 1,000 & 4,000 & 2,000 \\
\hline & VH1 & 3,000 & 12,000 & 48,000 & 3,000 & 12,000 & 6,000 & 3,000 & 12,000 & 6,000 \\
\hline \multirow{6}{*}{ Follow-up Bid } & VL21 & 2,000 & 8,000 & 32,000 & 2,000 & 8,000 & 4,000 & 2,000 & 8,000 & 4,000 \\
\hline & VH21 & 4,000 & 16,000 & 64,000 & 4,000 & 16,000 & 8,000 & 4,000 & 16,000 & 8,000 \\
\hline & VL2h & 2,000 & 8,000 & 32,000 & 2,000 & 8,000 & 4,000 & 2,000 & 8,000 & 4,000 \\
\hline & VH2h & 6,000 & 24,000 & 96,000 & 6,000 & 24,000 & 12,000 & 6,000 & 24,000 & 12,000 \\
\hline & VL2z & 500 & 2,000 & 8,000 & 500 & 2,000 & 1,000 & 250 & 1,000 & 500 \\
\hline & VH2z & 1,500 & 6,000 & 24,000 & 1,500 & 6,000 & 3,000 & 1,500 & 6,000 & 3,000 \\
\hline
\end{tabular}




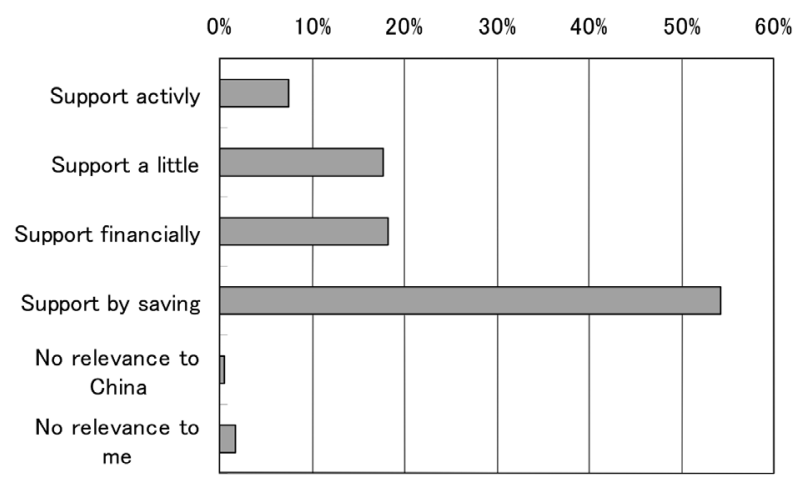

Fig. 2 Support intension for COP3

た。学校で習ったという回答の比率が低いのは, 温暖化問題 が最近 20 年弱に注目を浴びている問題であることも理由であ ると推測される。

次に，地球温暖化の緩和にどの程度協力できるかを質問し た。協力の度合いと “経済的負担” “省エネルギー”のどちら を嗜好するかを分析するために，選択肢は「生活様式の変更， 金銭的負担を含め，温暖化防止に積極的に協力したい。」，「あ る程度の生活上の不便，金銭的負担は享受できる。」,「生活は 変えたくないが，金銭的な負担はできる。」「金銭的な負担し たくないが，省エネ等は可能である。」，「中国には関係な い。」「自分には関係はない。」を準備した。回答分布をFig. 2 に示す。協力を一切しないという5-6 番目の選択肢を選んだ 回答者は少なく，54\%の回答者が「省エネ等は可能」を選ん でいた。この傾向は，日本国内に招ける同様な設問に対する
傾向 ${ }^{16)}$ と似ている。一方, 同調査ではでは省エネルギーより 金銭的負担を好む回答は $10 \%$ 未満であったが，今回の調査で は18\%の回答者が金銭的負担を選択していた。また，全体的 に日本より強い協力意志がある回答をする傾向が見られた。

\section{2 支払意志額についての分析}

喘息罹患を回避することについての経済価值評価を行うた めに, 回答者の経済価值評価額にモデルを当てはめ金額及び これに影響を与える要因を検討する。健康の経済価值換算を 行うに当たって，ここではVSLの計算と同様の考え方を用い る。死亡率 $r$ の変化 $\Delta r$ に対するWTP が $V$ のときにVSL は, $v / \Delta r$ として評価される。この考え方を適用すると, 罹患率が $10 \%$ から 4 \% 減少して $6 \%$ となること（事象 $\mathrm{AH}$ ) に対する WTP がVHで与えられたとき罹患回避の経済価值はVH/0.04 となり, 罹患率が $2 \%$ 減少して 8 \%になるWTPがVLで与え られたときの価值は，同様にVL/0.02 となる。質問では，三 肢選択を用いており，空気清浄機を購入することにより，10 \%であった喘息罹患率が $8 \%$ あるいは $6 \%$ になるものを購入 するかを質問している。回答者が選んだ選択肢により，VLな いしVHの存在範囲がFig. 1に示されたように決まる。これか ら, 選ばれた回答に対応する罹患回避の経済価值の存在範囲 が VH/0.02, VH/0.04により定められる。選ばれた選択肢によ り，VH，VLのいずれかによる範囲が定まる場合と，両方に よる範囲が定まる場合がある。両方の範囲が定まる場合は，い ずれの範囲にも含まれる領域を経済評価額の存在範囲とした。 データから得られた評価金額の存在範囲に基づいて, 評価金

Table 2 Estimated parameters for models

\begin{tabular}{|c|c|c|c|c|c|c|c|}
\hline Model & A1 & A2 & A3 & A4 & A5 & A6 & A7 \\
\hline Median & $59,776.7$ & $56,831.6$ & $53,976.2$ & $44,390.2$ & $52,556.6$ & $56,159.1$ & $55,197.9$ \\
\hline Log likelifood & -630.7 & -615.3 & -619.1 & -617.9 & -583.3 & -586.0 & -587.8 \\
\hline AIC & $1,265.5$ & $1,248.6$ & $1,244.1$ & $1,241.8$ & $1,202.6$ & $1,195.9$ & $1,191.7$ \\
\hline $\mathrm{a}$ & $-5.44(-11.8)$ & $-5.02(-8.6)$ & $-4.79(-9.8)$ & $-5.13(-10.8)$ & $-3.73(-5.0)$ & $-3.84(-6.0)$ & $-4.24(-7.4)$ \\
\hline $\mathrm{b}$ & $0.49(12.2)$ & $0.51(12.2)$ & $0.51(12.2)$ & $0.51(12.2)$ & $0.57(12.3)$ & $0.56(12.3)$ & $0.56(12.3)$ \\
\hline $\mathrm{I} 2 \mathrm{c}$ & & $-0.31(-0.7)$ & & & $-0.46(-1.0)$ & & \\
\hline I3c & & $0.00(0.0)$ & & & $-0.09(-0.2)$ & & \\
\hline $\mathrm{I} 4 \mathrm{c}$ & & $-0.59(-1.5)$ & & & $-0.45(-1.1)$ & & \\
\hline $\mathrm{I} 5 \mathrm{c}$ & & $-0.72(-1.8)$ & & & $-0.57(-1.3)$ & & \\
\hline I6c & & $-0.79(-1.9)$ & & & $-0.81(-1.8)$ & & \\
\hline I7c & & $-1.75(-3.6)$ & & & $-1.72(-3.3)$ & & \\
\hline $\mathrm{I} 8 \mathrm{c}$ & & $-2.27(-3.0)$ & & & $-2.04(-2.5)$ & & \\
\hline \multicolumn{8}{|l|}{ IA1c } \\
\hline IA2c & & & $-0.24(-4.7)$ & & & $-0.28(-4.0)$ & $-0.28(-4.0)$ \\
\hline $\mathrm{Ed} 2 \mathrm{c}$ & & & & $-0.32(-5.0)$ & $-0.83(-2.6)$ & $-0.80(-2.5)$ & $-0.74(-2.4)$ \\
\hline Ed3c & & & & & $-1.24(-3.6)$ & $-1.23(-3.6)$ & $-1.11(-3.4)$ \\
\hline $\mathrm{Lpc}$ & & & & & $-0.87(-3.1)$ & $-0.88(-3.2)$ & $-0.87(-3.2)$ \\
\hline Po2c & & & & & $-0.65(-2.5)$ & $-0.64(-2.5)$ & $-0.56(-2.7)$ \\
\hline Po3c & & & & & $-1.71(-5.3)$ & $-1.69(-5.4)$ & $-1.58(-5.7)$ \\
\hline Po4c & & & & & $-0.21(-0.5)$ & $-0.21(-0.6)$ & \\
\hline Fmc & & & & & $-0.26(-1.4)$ & $-0.24(-1.4)$ & \\
\hline Mrc & & & & & $-0.54(-1.4)$ & $-0.49(-1.3)$ & \\
\hline Che & & & & & $0.39(1.1)$ & $0.31(0.9)$ & \\
\hline
\end{tabular}


額が $\mathrm{x}$ より小さい確率が対数ロジスティック分布

$$
F(x)=\frac{1}{1+e^{a+\Sigma_{i} c_{i} z_{i}+b \log x}}
$$

に従っていると仮定してパラメータ $a ， b ， c_{i}$ を最尤法により 推定した。ここで，パラメータ bは金額が増加するに従い支 払う回答者の割合が減少する割合を表すパラメータ，パラ メータ a は分布の位置を決める定数項である。金額に対数を とっているため, aは金額のスケールとなり, bは分布の形を 表す。Ciは, 説明変数の WTPへの影響を表すパラメータで, 小さい程大きい程支払意志が強くなる。

Table 2 にパラメータの推定結果を示す。なお，回答者の 一部は世带年収に対する回答を行っていないため，推定は関 係する説明変数全てについての回答が得られている回答者に よるデー夕を用いた。括弧内に示した值は推定值を対数尤度 の二階微分から計算される漸近分散で除して求めた $t$ 值であ る。また， $-2 \cdot$ (対数尤度) $+2 \cdot$ (パラメータ数) で定義さ れる赤池情報量基準（Akaike's Information Criterion; AIC）を モデルの適合度を確認するため記した。AICの值が小さいほ どモデルがデータに適合していると考えることができる。説 明変数を導入せずに推定を行ったとき，10年間の喘息回避の 経済評価金額は約 59,800 元となった。なお，調査時点での中 国元の為替レートは約 16 円/元であるため, 日本円に直すと 96 万円程度となる。経済評価金額は世帯年収等の経済的条件 の影響を受けると考えられるが，世帯年収についての回答は， 6 万元 8 万元という回答が最も多く，次いで 4 万元 6 万 元という回答が多かった。提示されたシナリオに対する支払 意志額は年収金額程度に相当する。

ここで用いている最尤推定量は，漸近的に対数尤度の二階 微分からなる行列の逆行列を分散共分散行列とした正規分布 に法則収束する。今の場合,

$$
\left(\begin{array}{cc}
\frac{\partial^{2} L}{\partial a^{2}} & \frac{\partial^{2} L}{\partial a \partial b} \\
\frac{\partial^{2} L}{\partial a \partial b} & \frac{\partial^{2} L}{\partial b^{2}}
\end{array}\right)=\left(\begin{array}{cc}
144.3 & 1,620 \\
1,620 & 18,806
\end{array}\right)
$$

と計算された。ここでLは対数尤度関数を表す。モデルA1の メジアンの值を推定されたパラメータ近傍で線形近似し，パ ラメータ a，bの分布の正規近似より計算される $95 \%$ 信頼区間 は39,920元〜 79,630元と推定された。今回の調査では, サン プル数が 500 であり誤差を小さくするのは困難であった。サ ンプル数を増加すれば，推定誤差は減少していくことになる。

\section{3 世帯収入が支払意志額に与える影響の分析}

モデルA2以降は，どの様な要因が支払意志額に影響を与え ているかを分析するために説明変数を導入してモデルを当て はめたものである。説明変数には, 世帯年収, 学歴, 呼吸器 系疾患罹患経験の有無, 性別, 婚姻歴, 子供の有無を取り上 げた。係数が正であると(1)式の形から支払を行うと回答する 確率が減少することから支払意志が弱くなり，係数が負で絶 対值が大きいほど支払意志が強いことになる。表中のメジア ンの值は，独立変数の值を与え (1) 式の右辺を $1 / 2$ とする金額 Xを各データについて求め，そのメジアンを計算したものであ
る。

世帯年収は，選択肢を選ぶ形式で質問している。質問時に 提示する選択肢は，年収 10 万元以下は 2 万元刻み，10万元 20 万元は 5 万元刻みとし, 他に 5 千元未満, 20 万元以上の選 択肢を設け，9段階とした。年収 2 万元以上を選んだ回答者 は少数だったため，高収入の 2 つの階級を合併して分析は 8 階級で行い, 各階級に対応してダミー変数を導入し，これに 対応したパラメータをI1c〜I8c とした。同定可能性を満たす ために収入がもっとも少ない階級に対応するI1cを零に固定し てI2c〜I8cを推定した。各パラメータは，一番年収の少ない 年収 5 千元未満の階層と比較した支払意志の強さを表し，(1) 式の形から值が小さい程支払意志が強いことになる。モデル A2は，各階層別にパラメータを推定したもので，収入の少な いところでは值が零に近く, 収入の増加に従い值が負で絶対 值が大きくなっている。Fig. 3 に(1) 式中にある $a+\sum C_{i} Z_{i}$ の収 入に関わる部分の変化を示す。今回はサンプルの数が必ずし も多くないためか，I2cからI8cまでの内で統計的に有意になっ たのはI7c及びI8cの 2 つであった。収入の増加に対して支払 意志が強くなる傾向を少ないパラメー夕で推定を行い分析す るために，収入を表すパラメータに線形の制約

$\mathrm{I}_{i} \mathrm{c}=(\mathrm{IA} 1 \mathrm{c}) \cdot(i-1)$

を課して推定を行ったものがモデル A3である。t值からパラ メータIA1cは負で統計的に有意であった。このため，世帯年 収が増加するに従い支払意志も強くなると考えることができ る。収入が少ない階層のいくつかのパラメー夕 $\mathrm{I}_{i} C$ 值は, Fig. 3に示した通り零に近い。このため，収入の低い 3 つの階層に ついて值が零とした

$$
\mathrm{I}_{i} C=\left\{\begin{array}{cc}
0 & i \leqq 3 \\
\text { IA } 2 c \cdot(i-3) & i \geqq 4
\end{array}\right.
$$

形になるモデルを推定し, モデル A4とした。モデル A3に比 べ僅かながらAICが減少しており，当てはまりが改善された。 これより，世帯年収がある程度大きくなってからWTPが増大 に転じると考えた方が自然であると解釈できる。

所得が多い程支払意志額が高くなることは，自然な結果だ と考えられ先行研究 10) 12) 13) でも所得が高い程支払意志額が多

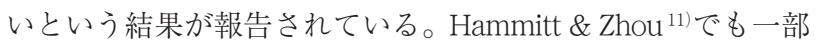
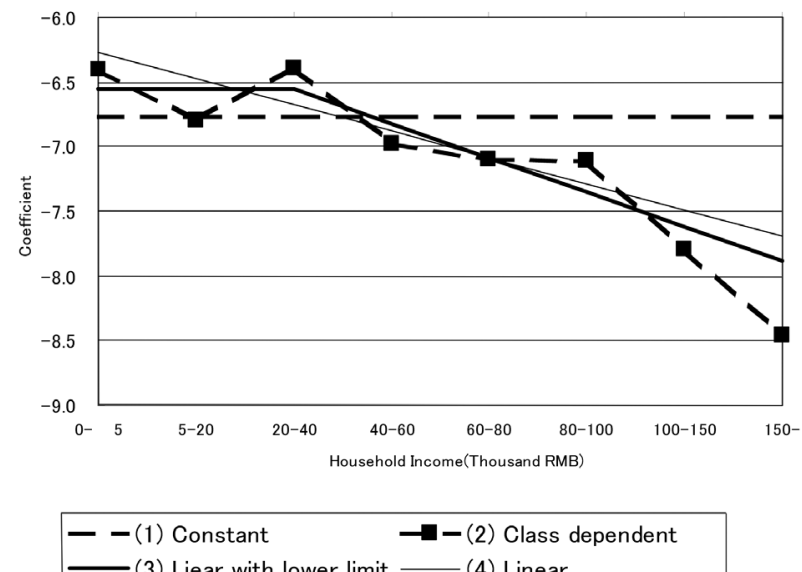

(3) Liear with lower limit _ (4) Linear

Fig. 3 Relationship between income and coefficients for WTP 
の推定係数について統計的に有意でないとされるものの，係 数の符号は同様な傾向を示していた。一方, Schläpfer ${ }^{17}$ では, 所得依存性の不検出は，回答者が予算制約についての認識が 弱いことを指摘しているが，ここでは所得依存性が検出され ており, 回答者がある程度真剣に回答していることが期待され る。

\section{4 その他の支払意志額に影響を与える要因の分析}

他の説明変数に対するパラメータも含めて推定を行ったの がモデル A4及びモデル A5である。学歴については, 最終学 歴を「小学校, 初級中学校」,「高級中学, 職業学校」,「短期 大学, 大学」「大学院」にその他を加えた選択肢を選ぶ形式で 質問している。前 3 者に対応してパラメータEd1c, Ed2c, Ed3c を導入した。大学院を選択した回答者は 10 名以下であったの で $\mathrm{Ed} 3 \mathrm{c}$ に対応した分類に統合し，Ed1c を零に固定して推定 を行った。Ed2c，Ed2cは負で有意であり，パラメータの值か らは，学歴が高い程支払意志が強いという傾向が検出された。

回答者の健康状態と大気污染についての認識は，支払意志 に影響する可能性がある。健康状態に何らかの不安がある場 合は，健康に関わる支出について積極的になるであるであろ うと素朴な感覚からは予想される。一方, Alberini et al. ${ }^{18)}$ が 分析を行ったように，各人が生命価值を経済価值換算し購入 の有無を意志決定するという考え方にたつと, 空気清浄機を 購入することにより得られる生命の質と，空気清浄機を購入 しない場合の生命の質との差を経済価值換算したものが, WTPの上限となる。この考え方だと, 現在の健康状態が悪い ことにより大気污染による喘息罹患を回避することによる便 益は，健康なひとのそれより少なくなる可能性もあり得るこ とになる。呼吸器系疾患の罹患歴は，CVMに関わる三肢選択 の質問を行う直前で，現在罹患しているか，過去に罹患した ことがあるかを質問している。疾患に罹っている回答者は 3 \%弱であったが，過去に罹患した回答者を含めると $20 \%$ 程度 の回答者が呼吸器系の病気に罹ったことがあるとしていた。 現在罹患している回答者も含めて罹患経験がある回答者に対
するダミー変数を導入し，対応するパラメータをLpcとした。 推定を行うと值からパラメータは負で有意であり, 呼吸器系 疾患の罹患経験があると支払意志が強くなる傾向がある。大 気污染の現状についても，CVM に関わる設問の前に質問を 行った。選択肢は,「大気污染の問題はない。」,「大気污染は あるが，段々良くなってきている。，「更に悪くなってきてい る。,「問題があり, 良くも悪くもなっていない。」,「その他」 から選択する形式とした。「その他」を選んだ回答者はいな かった。他のパラメー夕と同様に後三者に対してパラメータ Po2c，Po3c，Po4cを対応させた。Po2c，Po3cは有意に負であ りPO4cについては有意性は検出されなかった。大気污染につ いて, 改善, 悪化について変化があると考える回答者につい て, 問題がないか変化がないとした回答者に比べて支出意志 が強いという傾向になった。

性別については，女性についてパラメータ Fmc，婚姻歴は $\mathrm{Mrc}$ ，子供の有無についてはChcを回答にもとづきダミー変数 を設定しパラメータを推定した。いずれも值から統計的に有 意ではなく，支払意志に与える影響は検出されなかった。(1) 式に従うモデルとしてデータにもっとも適合していたのは, モデルA7で, 年収について収入についてはある程度増加して から支払意志額が増えていき，高学歴，喘息罹患経験有，大 気污染の状況に変化があると認識している方が，支払意志強 くなる傾向が見られた。

CVMでは，質問法等が回答に影響を及ぼすバイアスが誤差 要因として懸念されることがある。本調査では, Table 1で示 した提示金額が異なる 9 種類の調査票が用いられているが, 初期提示金額は金額順に $\mathrm{A} 1 ， \mathrm{C} 2 ， \mathrm{~B} 1, \mathrm{C} 1$ の 4 種類であり，例 えばA2，A3 は A1 と同一である。C2，B1，C1 と同一の調査 票を用いられた回答に対して 1 となるダミー変数 Frm 2, Frm3，Frm4 を導入し，他はモデル A1，A7 と同様なモデル B1，B7 の推定結果をTable 3 に示す。提示額が他に比べて極 端に高額である C1 の調査票を用いるとWTP が高めに出る傾 向があるものの，推定のばらつきに比べると影響は小さい。モ デル $\mathrm{C} 1, \mathrm{C} 7$ は，モデル $\mathrm{A} 1 ， \mathrm{~A} 7$ と同様な推定を調査票 $\mathrm{C} 1$ を

Table 3 Estimated parameters with starting value type

\begin{tabular}{|c|c|c|c|c|c|c|}
\hline Model & $\mathrm{B} 1$ & B7 & $\mathrm{C} 1$ & $\mathrm{C} 7$ & D1 & D7 \\
\hline Median & $53,636.3$ & $54,688.0$ & $56,040.7$ & $51,920.1$ & $53,174.6$ & $55,710.7$ \\
\hline Log likelifood & -626.5 & -583.0 & -608.5 & -566.6 & -605.9 & -564.4 \\
\hline AIC & $1,263.0$ & $1,188.0$ & $1,221.0$ & $1,149.3$ & $1,219.8$ & $1,148.8$ \\
\hline $\mathrm{a}$ & $-5.46(-11.4)$ & $-4.29(-7.3)$ & $-5.29(-11.4)$ & $-4.06(-7.0)$ & $-5.30(-11.1)$ & $-4.06(-6.9)$ \\
\hline $\mathrm{b}$ & $0.50(12.2)$ & $0.57(12.3)$ & $0.48(11.9)$ & $0.55(11.9)$ & $0.49(11.9)$ & $0.55(11.9)$ \\
\hline IA2c & & $-0.29(-4.1)$ & & $-0.28(-4.0)$ & & $-0.28(-3.9)$ \\
\hline $\mathrm{Ed} 2 \mathrm{c}$ & & $-0.75(-2.4)$ & & $-0.79(-2.5)$ & & $-0.81(-2.5)$ \\
\hline Ed3c & & $-1.11(-3.4)$ & & $-1.13(-3.4)$ & & $-1.16(-3.4)$ \\
\hline $\mathrm{Lpc}$ & & $-0.91(-3.3)$ & & $-0.90(-3.3)$ & & $-0.91(-3.3)$ \\
\hline Po2c & & $-0.52(-2.5)$ & & $-0.56(-2.6)$ & & $-0.54(-2.5)$ \\
\hline Po3c & & $-1.56(-5.6)$ & & $-1.56(-5.6)$ & & $-1.54(-5.5)$ \\
\hline Frm2 & $0.23(1.1)$ & $0.23(1.0)$ & & & $0.23(1.1)$ & $0.23(1.0)$ \\
\hline Frm3 & $-0.27(-1.3)$ & $-0.26(-1.2)$ & & & $-0.27(-1.3)$ & $-0.26(-1.2)$ \\
\hline Frm4 & $-0.83(-1.8)$ & $-1.10(-2.3)$ & & & & \\
\hline
\end{tabular}


用いた以外のデータで推定したもので，D1，D7は同様のデー 夕にB1，B7のモデルを適用したものである。AICの值につい てはD1，D7がC1，C7より小さく好まれているが，その差は 小さく尤度比検定で D 1 と C1 を比較するとむしろ C1 が選択 される。C7 も同様である。調査票 $\mathrm{C} 1$ は, 提示額の範囲を絞 るために非常に高額の提示をしており，他の調査票に比べ分 布がひずんでいる可能性がある。しかしながら, 提示額によ る差がWTP推定值，モデルの係数に与える影響は推定誤差に 比べさかった。一方, 今回の評価対象は自分自身の健康に 対する被害を低減させる機器の購入であり, その便益は回答 者人に独占されるため, Warm growバイアス等は小さいこと が期待されるが，より深いバイアスについての検討は今後の 課題でもある。

\section{4. 結 言}

中国上海市において，環境意識の調査を行い，大気污染に 起因する健康リスクの減少に対する支払意志額の分析を行っ た。支払意志額についての設問では，多用されている二段階 二肢選択法を拡張した，二段階三肢選択法を適用した。VSLの 計算法と同じ考え方で推測すると，今後10年間の喘息罹患リ スクを減少させるための経済価值の大きさは 6 万元程度と なった。喘息罹患についての経済価值に換算した金額は，ラ イフサイクルアセスメントに抄けるインパクト分析における 定量化に有益な情報を与える。支払意志額は，世带年収の影 響を受けていた。世帯年収が増大するに従い支払意志は強く なるものの，収入が低いときには依存性は弱く，ある程度年 収が多くなってから支払意志も強くなる傾向があった。また, 支払意志額には年収の他に，学歴喘息罹患経験，大気污染の 状況についての認識が影響を及ぼしていた。

\section{謝 辞}

本研究の調査分析は，環境省による地球環境研究総合推進 費（B-074）及び環境研究総合推進費（E1001）の支援により 実施されました。研究の機会を与えられたことに謝意を表し ます。また，査読者の方々の貴重なコメントは，論文の修正 において有益でした。記して御礼申し上げます。

\section{文 献：References}

1) Bickel, P., Friedrich, R., Externalities of Energy Methodology 2005 Update, Directorate-General for Research Sustainable Energy Systems (2005)

2) Hainoun, A., Almoustafa A., Aldin, M. S., Energy, 35, 628-638
(2010)

3）伊坪徳宏, 稲葉敦 (編著), ライフサイクル環境影響評価手 法一LIME - LCA, 環境会計, 環境効率のための評価手 法・データベース，(産業環境管理協会)，(2005）：Itsubo, N., Inaba, A.(Ed.), Raifusaikuru Kankyoeikyo Hyokashuhou, (Japan Environmental Management Association for Industry), (2005)

4) 古川俊一, 磯崎肇, 日本評価研究, 4, 53 (2004): Furukawa, S., Isozaki, H., The Japanese journal of evaluation studies, 4, $53(2004)$

5）栗山浩一, 公共事業と環境の価值, (築地書館), (1997) : Kuriyama, K., Contingent Valuation Method: Theory and Practice, (Tsukiji Shokan), (1997)

6）竹内憲司, 環境評価の政策利用, (勁草書房), (1999)： Takeuchi, K., Kankyouhyouka no Seisakuriyou, (Keiso shobo), (1999)

7）鷲田豊明，環境評価入門，(勁草書房)，(1999）：Washida T.,Kankyo Hyoka Nyumon, (Keiso shobo), (1999)

8) Pearce D., Energy Policy, 24, 627 (1996)

9) Soubbotina, T. P., Beyond economic growth: meeting the challenges of global development, World Bank, (2000)

10) Wang, H., Mullahy, J., Science of the Total Environment, 367, 50 (2006)

11) Hammitt, J. K., Zhou, Y., Environmental \& Resource Economics, 33, $399(2006)$

12) Wang, X. J., Zhang, W., Li , Y., Yang, K. Z., Bai, M., Environmental Monitoring and Assessment, 120, 153(2006)

13) Wang, Y., Zhang, Y., Journal of Environmental Management, 90, $1022(2009)$

14）松岡俊二, 白川博章, 本田直子, 竹内憲治, 松本礼史, 国 際東アジア研究センター Working Paper Series Vol.200210(2002) : Matsuoka, S., Shirakawa, H., Honda, N., Takeuchi, K., Matsumoto, R., The International Center for the Study of East Asian Development Working Paper Series Vol. 2002$10(2002)$

15) Loomis, J., Traynor, K., Brown, T., Journal of Agricultural and Resource Economics, 24, 572 (1999)

16）野村昇, 日工市誌，88, 140 (2009)：Nomura, N., J.Jpn.Inst. Energy, 88, 140 (2009)

17) Schläpfer, F., Ecological Economics, 57, 415(2006)

18) Alberini, A., Cropper, M., Krupnick, A., Simon, N. B., Journal of Environmental Economics and Management, 48, 769 (2004) 